\title{
Edaphic Filters and Plant Colonization in a Mine Revegetated with Sewage Sludge
}

\author{
Alexander Balduíno $^{1}$ (D), Rodrigo Corrêa ${ }^{1}$, Cássia Beatriz Rodrigues Munhoz ${ }^{1}$ (D), \\ Roberta Chacon ${ }^{2}$ (D), José Roberto Rodrigues Pinto ${ }^{1}$ \\ ${ }^{1}$ Universidade de Brasília - UnB, Brasília/DF, Brasil \\ ${ }^{2}$ Jardim Botânico de Brasília, Brasília/DF, Brasil
}

\begin{abstract}
We evaluated the recruitment of plant species and their relation with edaphic attributes in a mine revegetated with sewage sludge in the Brazilian Federal District. Plant species in the revegetated mine and in remaining portions of Cerrado (savanna) within the mined landscape were sampled and identified. Then, samples of revegetated substrate and soils from Cerrado portions were collected, analyzed for chemical attributes and submitted to statistical tests. Results indicated that the remaining portions of Cerrado were colonized by 91 species (22\% allochthonous species), and the revegetated substrate housed 62 species (55\% allochthonous species). Multivariate tests showed that the edaphic condition built from the incorporation of sewage sludge into the mining substrate acted as filter on the assemblage of plant species. Despite the two study sites shared the same landscape, the Cerrado portions and the revegetated substrate did not share similar plant communities after a decade from mine rehabilitation works.
\end{abstract}

Keywords: plant recruitment, ecological restoration, biosolids, Cerrado. 


\section{INTRODUCTION}

Surface mining is one of the most severe forms of environmental degradation and anthropogenic alteration of habitats (Wijesekara et al., 2016). Vegetation removal and soil excavation for reaching minerals drastically reduce ecosystem resilience and its functions (Domene et al., 2010; Corrêa et al., 2017). Surface mining in the Brazilian Federal District (BFD) is based on low investments in operations, small mining extensions, and poor control over mineral exploration, impact mitigation, and ecological restoration (Corrêa et al., 2004).

Substrates exposed to the surface by mining present inappropriate conditions for the establishment of plants and other organisms (Goedert \& Corrêa, 2004; Corrêa \& Bento, 2010), and the incorporation of high rates of organic matter into substrates (> $50 \mathrm{Mg}$. ha ${ }^{-1}$ dry basis) has been the solution to build a suitable edaphic environment on mined sites. Thus, the rehabilitation of exploited mines involves physical, chemical, and biological amendments of exposed substrates that along with propagules of regional species should trigger the autogenic succession in the revegetated sites (Corrêa et al., 2007).

Due to economic reasons and to stimulate recycling, urban residues, such as sewage sludge, have been applied to exploited mines as source of organic matter and plant nutrients since 1994 in the BFD (Corrêa, 2009). Sanitary issues that limit the use of sewage sludge in agriculture are not impediments for using it in mines (Corrêa, 2009). Increase of organic matter content, nutrient concentrations, and microbial biomass (Domene et al., 2010; Gardner et al., 2010; Torri et al., 2014; Wijesekara et al., 2016), improvement of physical attributes (De Maria et al., 2007; Jordán et al., 2017), and spontaneous revegetation of surfaces (Andrés et al., 2007; Borges et al., 2009; Silva et al. 2013) follow the incorporation of organic residues into mining substrates.

The processes that classify and restrict species establishment on a site during the course of ecological restoration are designated as ecological filters (Hulvey \& Aigner, 2014). The literature commonly identifies three major ecological filters: 1) limitations on seed dispersion or seed rain that prevent species to reach the restoration site (Funk et al., 2008; Oster et al., 2009); 2) abiotic local conditions that favor or difficult the establishment and survival of some group of species (Cleland et al., 2013; Sollenberger et al., 2016); 3) biotic interactions between species that limit (competition) or facilitate (facilitation) the establishment, persistence and abundance of some species on a site (Funk et al., 2008; Cleland et al., 2013).

Although some studies have offered an expressive contribution to the advance of knowledge on the rehabilitation of areas degraded by the mining (Corrêa et al., 2007; Corrêa, 2009; Daws et al., 2013; Nussbaumer et al., 2016; Wijesekara et al., 2016), few studies have investigated the role of edaphic filters in plant recruitment on sites revegetated with sewage sludge (Corrêa et al., 2017). Therefore, this study aimed to investigate the relation between edaphic filters and plant colonization in a gravel mine revegetated with sewage sludge, having remaining portions of the original soil and native vegetation within the mined landscape as references.

\section{MATERIAL AND METHODS}

The area of this study was located on the margin of the highway BR-060 (155' $6.45^{\prime \prime}$ S, 48 $10^{\circ} 40.42^{\prime \prime} \mathrm{W}$, Datum WGS 84) in the southwestern portion of the Brazilian Federal District (BFD), which extends for $5,814 \mathrm{~km}^{2}$ on the Brazilian Central Plateau. Regional topography varies from flat to gently sloped, with average altitude of $1,100 \mathrm{~m}$. Climate is Tropical of Savanna (Aw - Köppen Geiger) with well-defined wet and dry seasons. Annual mean temperature ranges from $21{ }^{\circ} \mathrm{C}$ to $24{ }^{\circ} \mathrm{C}$ and annual rainfall ranges from 1,200 to $1,600 \mathrm{~mm}$, with $95 \%$ of precipitation occurring between September and March.

Lateritic gravel was explored from the study site in 2001 and 2002, and mine operations left a 67 ha crater from 4 to $5 \mathrm{~m}$ bellow the original ground level (Figure 1). The original soil on the area was a Haplic Inceptisol - Cambissolo (EMBRAPA, 2013), which supported Cerrado sensu stricto vegetation type. Rehabilitation works involved the incorporation of $130 \mathrm{Mg} \mathrm{ha}^{-1}$ (dry basis) of domestic sewage sludge into the exposed substrate surface $(0-15 \mathrm{~cm})$ in 2002 . Urochloa brizantha $\left(7 \mathrm{~kg} \mathrm{ha}^{-1}\right)$ was sown on the rehabilitated substrate in 2005 , and since then the area has been used as pasture for approximately thirty bovines. Remaining portions of the original soil and Cerrado vegetation (mounds) 


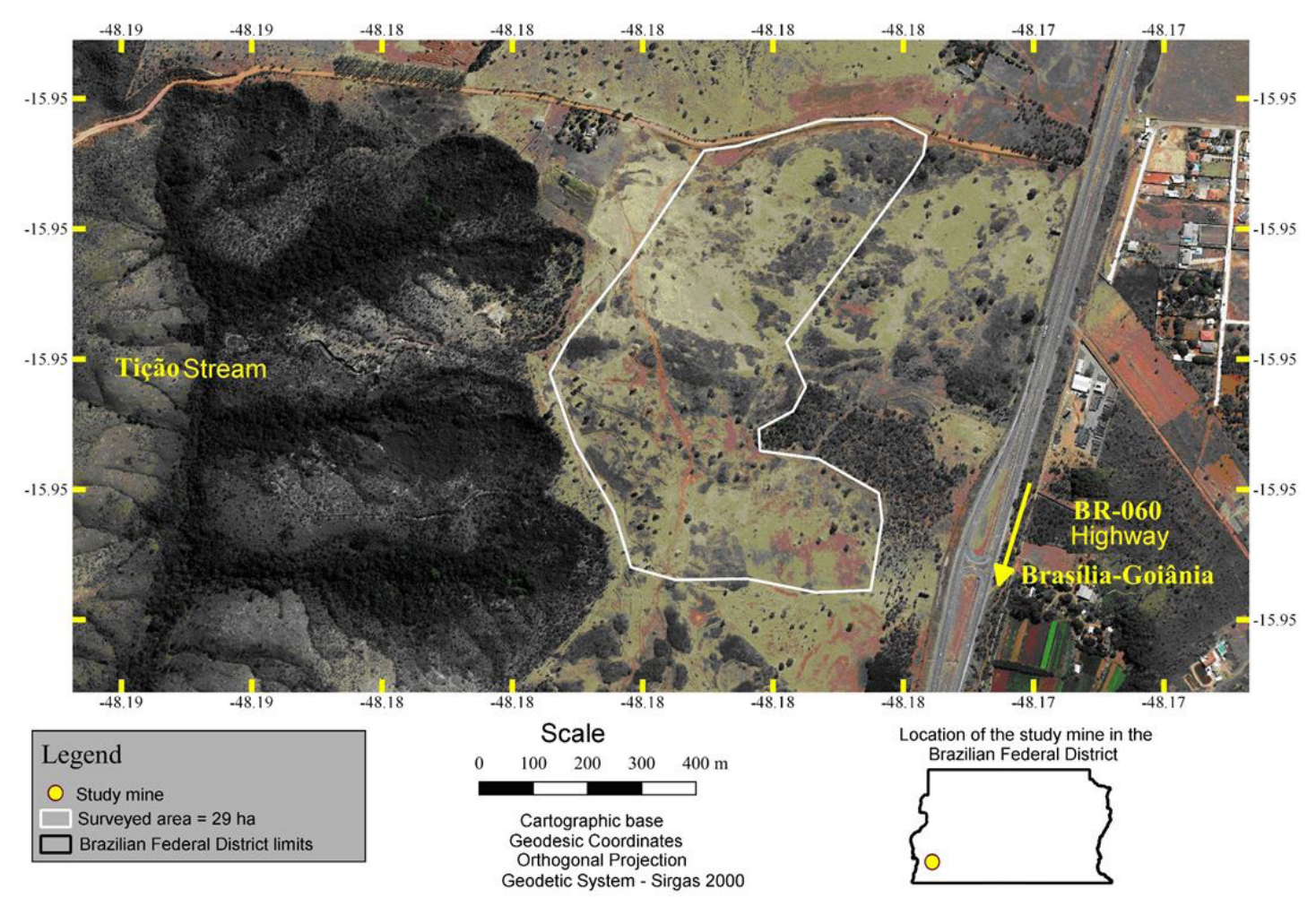

Figure 1. Location of the sampled 29 ha within the 67 ha mined site. Data source: Codeplan (2017).

were left in the midst of the mined landscape, just 4 - $5 \mathrm{~m}$ above mined surface. The Cerrado vegetation on mounds continued to produce seeds and propagules dispersed to the neighborhood.

A floristic survey of species naturally recruited in the rehabilitated mine substrate and in the remaining portions of Cerrado (mounds) was done ten years after sewage sludge incorporation into the exposed mine surface. Stratified sampling was chosen for the floristic survey due to the presence of two biotopes within the same site. Remaining portions of Cerrado (mounds) were selected at random and circular areas of $15 \mathrm{~m}$ radius were delimited around them on the rehabilitated mine surface (Figure 2). Rarefaction curves periodically tested the sampling sufficiency for each of the two biotopes until curves tended to stabilization, which was reached after sampling 15 mounds and respective areas on the rehabilitated substrate around them - 15 sampling units (Figure 3 ). The extension effectively sampled was $1.88 \mathrm{ha}$, of which $0.12 \mathrm{ha}$ on mounds and $1.76 \mathrm{ha}$ on the rehabilitated mine surface. All recruited plant species were recorded and three composite samples of soil and substrate (five subsamples - 0 to $15 \mathrm{~cm}$ depth) were collected from each sampling unit. Plant species not identified on the spot were photographed and collected for further identification in herbarium.

Names of sampled plant species were updated (Species Link, 2017), and species were classified according to life form (grass, bindweed grass, subshrub, shrub, or tree), origin (autochthonous or alochthonous to Cerrado formations), and invasion capacity of natural environments, rural areas, and pastures (Lorenzi, 2008; Mendonça et al., 2008).

Soil and substrate samples were air-dried, sieved $(2 \mathrm{~mm})$, and analyzed for organic matter (OM), total nitrogen (total-N), available phosphorus (available-P), exchangeable potassium (exchangeable-K), calcium $\left(\mathrm{Ca}^{2+}\right)$, magnesium $\left(\mathrm{Mg}^{2+}\right)$, active acidity $(\mathrm{pH})$, potential acidity $\left(\mathrm{H}^{+}+\mathrm{Al}^{3+}\right)$, cationic exchange capacity (CEC), and base saturation (V\%). The analysis of organic matter (OM) followed the method of humid combustion (Walkley-Black) and posterior titration with an ammoniac ferrous sulphate solution. Total nitrogen was analyzed by the Kjeldahl method. Available-P and 


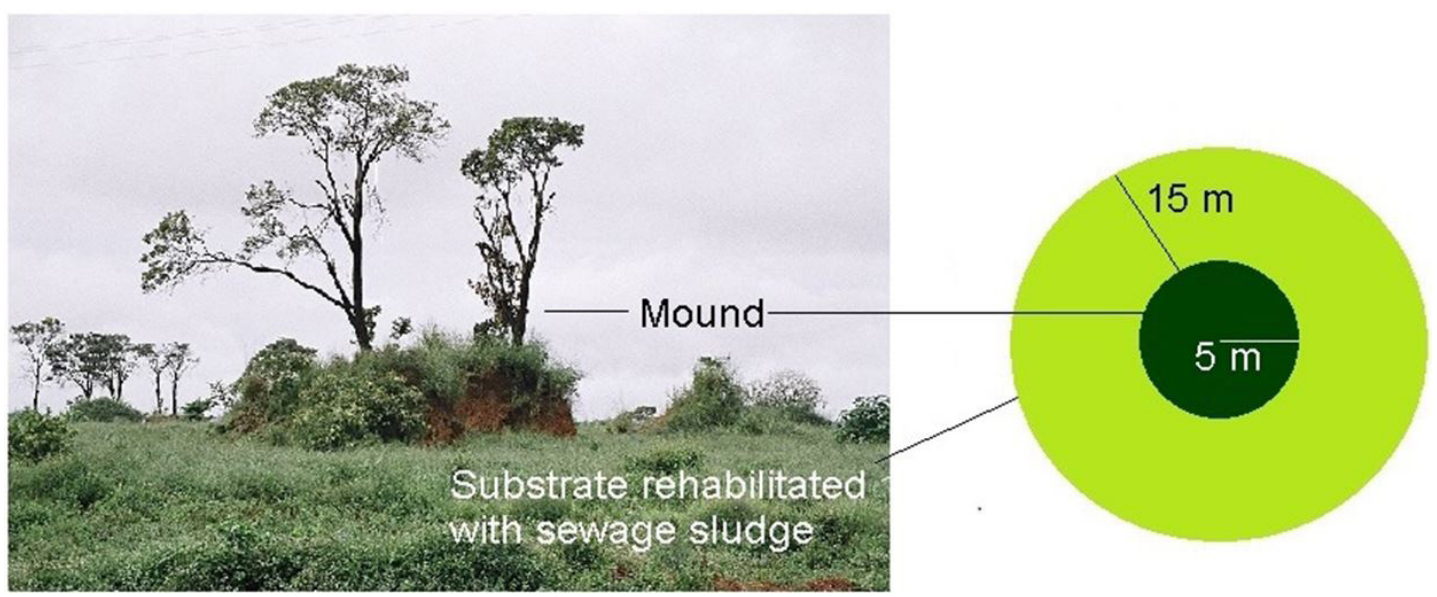

Figure 2. Sampling unit designed according to mound locations (D1 to D15) and surround areas. The dark green circle regards to the area on mounds and the light green circle to the area on the revegetated substrate around mounds.

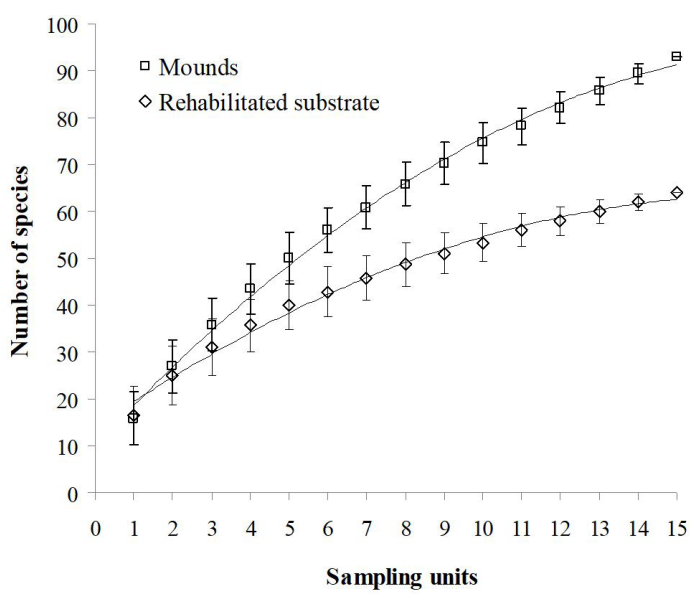

Figure 3. Rarefaction curves of plant species sampled on mounds and on the substrate rehabilitated with sewage sludge.

exchangeable-K were extracted with Mehlich-1 solution and concentrations were respectively determined in a photocolorimeter and spectrophotometer of atomic absorption. $\mathrm{Ca}^{2+}$ and $\mathrm{Mg}^{2+}$ were extracted with $\mathrm{KCl}$ solution and analyzed by spectrophotometer of atomic absorption. Soil and substrate samples were shaken with $0.01 \mathrm{M} \mathrm{CaCl}_{2}$ solution and analyzed for active acidity in a pH meter. Potential acidity was determined by means of a buffered solution of calcium acetate and subsequent titration with $\mathrm{NaOH}$. From the obtained results, CEC and V\% were calculated according to Embrapa (1997).
Results were submitted to analysis of variance, test of Student, and Mood Median test in Minitab 15 software. The influence of the edaphic attributes on the distribution of recruited plant species was investigated by using the Canonical Correspondence Analysis (CCA). The CCA examines responses of species and sampling units to environmental variables. Thus, unlike other ordination techniques, the CCA provides a direct analysis of gradients (Ter Braak, 1987). To meet CCA prerequisites, data were organized into two matrices and processed in R 3.3.1 version software ( $\mathrm{R}$ Core Team, 2016). Plant species matrix contained categorical values (presence $=1$ and absence $=0$ ). We used only the species that occurred in at least two of the 15 sampled units and eliminated accidental species from the CCA (Dajoz, 2005). This procedure is recommended in ordination techniques, because accidental species do not significantly affect results but increase the volume of calculations and errors (Gauch, 1982). The metric values of the edaphic attributes constituted the second matrix. To test the probability of relation between the matrices of plant species and edaphic attributes, we used the Monte Carlo permutation test (Ter Braak \& Prentice, 1988). Flora similarity between mounds and rehabilitated substrate was evaluated by Anosim test, and the correlation between ordinations of sampling units depending on species composition and edaphic conditions was analyzed by Procrustes test. 


\section{RESULTS}

Rarefaction curves indicated that the sampling of 15 remaining portions of Cerrado (mounds) and the respective surroundings was enough to represent the flora of the study area (Figure 3). It was found 131 plant species colonizing the soil on mounds and the rehabilitated substrate ten years after the incorporation of sewage sludge into the exposed mined surface. Out the 131 plant species, 91 appeared on mounds, of which $76 \%$ were unique to this biotope, $22 \%$ allochthonous, $38 \%$ invasive, $45 \%$ trees, $18 \%$ shrubs, and $40 \%$ herbs/subshrubs. Sixty two species recruited on the rehabilitated substrate, of which $65 \%$ were unique to this other biotope, being $55 \%$ allochthonous, $83 \%$ invasive, $14 \%$ trees, $16 \%$ shrubs, and $73 \%$ herbs/subshrubs (Table 1).
Sewage sludge applied at $130 \mathrm{Mg} \mathrm{ha}^{-1}$ (dry basis) to the exposed substrate resulted in high fertility levels in relation to the values found in soils on mounds (Table 2). The concentration of available-P in the rehabilitated substrate, for instance, reached 46 times the value found in the original Cerrado soil (Table 2). The other edaphic attributes also presented significantly different values in the two biotopes, except potential acidity $\left(\mathrm{H}^{+}+\mathrm{Al}^{3+}\right)$ (Table 2$)$.

Eigenvalues for axes 1 and 2 from the Canonical Correspondence Analysis (CCA) were 0.19 and 0.54, respectively. Axis 1 explained $16.2 \%$ of the variance and axis $2,5.9 \%$ of the same. The low $22.1 \%$ variance is common in ecological data ordinations due to the complexity of factors involved in the determination of communities' floristic compositions (Ter Braak \& Prentice, 1988). Monte Carlo permutation test was

Table 1. Sampled plant species in the study area.

\begin{tabular}{|c|c|c|c|c|}
\hline Species & Life form & Origin & Invasive? & Location \\
\hline Acanthospermum australe (Loefl.) Kuntze & herb & allochthonous & yes & $\mathrm{D}$ \\
\hline Achyrocline satureoides (Lam.) DC. & herb & autochthonous & yes & $\mathrm{S}$ \\
\hline Acosmium dasycarpum (Vogel) Yakovl & tree & autochthonous & no & $\mathrm{D}$ \\
\hline Aegiphila lhotzkiana Cham. & tree & autochthonous & no & $\mathrm{D}$ \\
\hline Ageratum conyzoides L. & herb & allochthonous & yes & $\mathrm{D} / \mathrm{S}$ \\
\hline Alibertia cf sessilis (Vell.) K. Schum. & tree & autochthonous & no & $\mathrm{D}$ \\
\hline Amaranthus sp & herb & - & - & $\mathrm{S}$ \\
\hline Annona crassiflora Mart. & tree & autochthonous & no & $\mathrm{D}$ \\
\hline Annona tomentosa R.E.Fr. & shrub & autochthonous & no & $\mathrm{D}$ \\
\hline Asclepias cf curassavica L. & herb & allochthonous & yes & $\mathrm{D} / \mathrm{S}$ \\
\hline Aspidosperma tomentosum Mart. & tree & autochthonous & no & $\mathrm{D}$ \\
\hline Asteraceae sp1 & herb & - & - & S \\
\hline Asteraceae sp2 & herb & - & - & $\mathrm{D}$ \\
\hline Axonopus capillaris (Lam.) Chase & herb & autochthonous & no & $\mathrm{D}$ \\
\hline Bauhinia sp & shrub & - & - & $\mathrm{D}$ \\
\hline Borreria latifolia (Aubl.) K. Schum. & herb & autochthonous & $\operatorname{sim}$ & $\mathrm{D}$ \\
\hline Byrsonima coccolobifolia Kunth & tree & autochthonous & no & $\mathrm{D}$ \\
\hline Byrsonima sp1 & - & - & - & $\mathrm{D}$ \\
\hline Casearia silvestris Sw. & tree & autochthonous & no & $\mathrm{D}$ \\
\hline Cecropia cf pachystachya Miq. & tree & autochthonous & yes & $\mathrm{S}$ \\
\hline Chamaecrista rotundifolia (Pers.) Greene & herb & allochthonous & yes & $\mathrm{D}$ \\
\hline Cissampelos $\mathrm{sp}$ & climbing herb & - & - & $\mathrm{D}$ \\
\hline Cleome spinosa Jacq. & sub-shrub & allochthonous & yes & $\mathrm{S}$ \\
\hline Commelinaceae sp & climbing herb & - & - & $\mathrm{S}$ \\
\hline Connarus suberosus Planch. & tree & autochthonous & yes & $\mathrm{D}$ \\
\hline Copaifera langsdorffii Desf. & tree & autochthonous & no & $\mathrm{D}$ \\
\hline Cucurbitaceae sp & climbing herb & - & - & $\mathrm{S}$ \\
\hline
\end{tabular}

$\mathrm{D}=$ mounds $\mathrm{S}=$ substrate rehabilitated with sewage sludge. 
Table 1. Continued...

\begin{tabular}{|c|c|c|c|c|}
\hline Species & Life form & Origin & Invasive? & Location \\
\hline Cyperus surinamensis Rottb. & herb & autochthonous & yes & S \\
\hline Cyperus cf odoratus L. & herb & allochthonous & yes & S \\
\hline Dalbergia miscolobium Benth. & tree & autochthonous & no & $\mathrm{D}$ \\
\hline Davilla elliptica A.St.-Hil. & tree & autochthonous & no & $\mathrm{D} / \mathrm{S}$ \\
\hline Digitaria insularis (L.) Fedde & herb & allochthonous & yes & S \\
\hline Dimorphandra mollis Benth. & tree & autochthonous & yes & S \\
\hline Diospyros burchellii Hiern & tree & autochthonous & no & $\mathrm{D}$ \\
\hline Emilia fosbergii Nicolson & herb & allochthonous & yes & $\mathrm{D} / \mathrm{S}$ \\
\hline $\begin{array}{l}\text { Eriotheca pubescens (Mart. \& Zucc.) Schott \& } \\
\text { Endl. }\end{array}$ & tree & autochthonous & no & $\mathrm{D}$ \\
\hline Erythroxylum deciduum A. St.-Hil & tree & autochthonous & no & $\mathrm{D}$ \\
\hline Erythroxylum sp & tree & - & - & $\mathrm{D}$ \\
\hline Erythroxylum tortuosum Mart. & tree & autochthonous & no & $\mathrm{D}$ \\
\hline Eugenia dysenterica DC. & tree & autochthonous & no & $\mathrm{D}$ \\
\hline Fabaceae sp & - & - & - & $\mathrm{D}$ \\
\hline Handroanthus ochraceus (Cham.) Mattos & tree & autochthonous & no & $\mathrm{D}$ \\
\hline Hortia brasiliana Vand. ex DC. & shrub & autochthonous & no & $\mathrm{D}$ \\
\hline Hymenaea stigonocarpa Mart. ex Hayne & tree & autochthonous & no & $\mathrm{D}$ \\
\hline Hyptis suaveolens (L.) Poit. & sub-shrub & allochthonous & yes & $\mathrm{D} / \mathrm{S}$ \\
\hline Ipomoea nil (L.) Roth & climbing herb & allochthonous & yes & $\mathrm{S}$ \\
\hline Ipomoea triloba $\mathrm{L}$. & climbing herb & allochthonous & yes & S \\
\hline Jacaranda ulei Bureau \& K.Schum. & shrub & autochthonous & no & $\mathrm{D}$ \\
\hline Lamiaceae sp1 & herb & - & - & $\mathrm{D} / \mathrm{S}$ \\
\hline Lantana camara L. & sub-shrub & allochthonous & yes & $\mathrm{D}$ \\
\hline Leonotis nepetifolia (L.) R. Br. & herb & allochthonous & yes & $\mathrm{S}$ \\
\hline Lepidaploa aurea (Mart. ex DC.) H.Rob. & shrub & autochthonous & no & $\mathrm{D} / \mathrm{S}$ \\
\hline $\begin{array}{l}\text { Lippia cf alba (Mill.) N.E. Br. ex Britton \& P. } \\
\text { Wilson }\end{array}$ & sub-shrub & allochthonous & yes & $\mathrm{D}$ \\
\hline Ludwigia cf tomentosa (Cambess.) H. Hara & sub-shrub & autochthonous & yes & S \\
\hline Malvastrum coromandelianum (L.) Garcke & sub-shrub & allochthonous & yes & $\mathrm{S}$ \\
\hline Maprounea guianensis Aubl. & tree & autochthonous & no & $\mathrm{D}$ \\
\hline Melia azedarach L. & tree & allochthonous & no & S \\
\hline Miconia stenostachya DC. & tree & autochthonous & no & $\mathrm{S}$ \\
\hline Mimosa caesalpiniifolia Benth. & tree & autochthonous & no & $\mathrm{S}$ \\
\hline Mimosa pigra L. & shrub & allochthonous & yes & $\mathrm{D} / \mathrm{S}$ \\
\hline Myrtaceae sp1 & - & - & - & $\mathrm{D}$ \\
\hline Myrtaceae sp2 & - & - & - & $\mathrm{D}$ \\
\hline Myrtaceae sp3 & - & - & - & $\mathrm{D}$ \\
\hline Não identificadas & - & - & - & $\mathrm{D} / \mathrm{S}$ \\
\hline Nicotiana tabacum L. & herb & allochthonous & no & $\mathrm{S}$ \\
\hline Ouratea floribunda Engl. & shrub & autochthonous & no & $\mathrm{D}$ \\
\hline Pavonia sp & sub-shrub & - & - & $\mathrm{D}$ \\
\hline Pennisetum setosum (Sw.) Rich. & herb & allochthonous & yes & S \\
\hline Piper aduncum L. & shrub & autochthonous & yes & $\mathrm{S}$ \\
\hline Plathymenia reticulata Benth. & tree & autochthonous & no & $\mathrm{D}$ \\
\hline Poaceae sp1 & herb & - & - & $\mathrm{S}$ \\
\hline Poaceae sp2 & herb & - & - & $\mathrm{D}$ \\
\hline Poaceae sp3 & herb & - & - & $\mathrm{S}$ \\
\hline Psidium myrsinoides O. Berg & tree & autochthonous & no & $\mathrm{D}$ \\
\hline
\end{tabular}

$\mathrm{D}=$ mounds; $\mathrm{S}=$ substrate rehabilitated with sewage sludge. 
Table 1. Continued...

\begin{tabular}{|c|c|c|c|c|}
\hline Species & Life form & Origin & Invasive? & Location \\
\hline Psidium pohlianum O. Berg & tree & autochthonous & no & $\mathrm{D}$ \\
\hline Qualea grandiflora Mart. & tree & autochthonous & no & $\mathrm{D}$ \\
\hline Ricardia sp & - & - & - & $\mathrm{D}$ \\
\hline Ricinus communis $\mathrm{L}$. & shrub & allochthonous & yes & S \\
\hline Roupala montana Aubl. & tree & autochthonous & no & $\mathrm{D}$ \\
\hline Rubiaceae sp & - & - & - & $\mathrm{D} / \mathrm{S}$ \\
\hline Scoparia dulcis L. & herb & allochthonous & yes & S \\
\hline Senna obtusifolia (L.) H.S. Irwin \& Barneby & sub-shrub & allochthonous & yes & $\mathrm{D} / \mathrm{S}$ \\
\hline Senna occidentalis (L.) Link & herb & allochthonous & yes & S \\
\hline Sida glaziovii K. Schum. & sub-shrub & autochthonous & yes & $\mathrm{D} / \mathrm{S}$ \\
\hline Sida rhombifolia L. & sub-shrub & allochthonous & yes & $\mathrm{D} / \mathrm{S}$ \\
\hline Sidastrum micranthum (A. St.-Hil.) Fryxell & herb & autochthonous & yes & $\mathrm{D} / \mathrm{S}$ \\
\hline Simarouba cf versicolor A. St.-Hil. & tree & autochthonous & no & $\mathrm{D}$ \\
\hline Smilax goyazana A. DC. & climbing herb & autochthonous & no & $\mathrm{D}$ \\
\hline Solanum americanum Mill. & shrub & allochthonous & yes & $\mathrm{D} / \mathrm{S}$ \\
\hline Solanum falciforme Farruggia. & tree & autochthonous & yes & $\mathrm{D} / \mathrm{S}$ \\
\hline Solanum palinacanthum Dunal. & shrub & autochthonous & yes & $\mathrm{D} / \mathrm{S}$ \\
\hline Solanum sp1 & - & - & - & $\mathrm{D}$ \\
\hline Solanum sp2 & - & - & - & $\mathrm{S}$ \\
\hline Solanum subumbellatum Vell. & shrub & autochthonous & no & $\mathrm{D}$ \\
\hline Stachytarpheta elatior Schrad. ex Schult. & sub-shrub & autochthonous & yes & $\mathrm{S}$ \\
\hline Stylosanthes guianensis (Aubl.) Sw. & herb & autochthonous & yes & $\mathrm{D} / \mathrm{S}$ \\
\hline Stylosanthes sp & herb & - & - & $\mathrm{D}$ \\
\hline Tabebuia roseoalba (Ridley) Sandw. & tree & autochthonous & no & $\mathrm{D}$ \\
\hline Tachigali vulgaris L.G.Silva \& H.C.Lima. & tree & autochthonous & no & $\mathrm{D}$ \\
\hline Tagetes minuta L. & herb & allochthonous & yes & $\mathrm{D} / \mathrm{S}$ \\
\hline Triumfetta rhomboidea Jacq. & sub-shrub & allochthonous & yes & S \\
\hline Urochloa plantaginea (Link) Hitchc. & herb & allochthonous & yes & $\mathrm{D} / \mathrm{S}$ \\
\hline Verbenaceae sp & - & - & - & S \\
\hline Vernonanthura ferruginea (Less.) H. Rob. & shrub & autochthonous & yes & $\mathrm{D} / \mathrm{S}$ \\
\hline Vernonia polyanthes Less. & shrub & autochthonous & yes & S \\
\hline Vernonia rubriramea Mart. ex DC. & shrub & autochthonous & no & $\mathrm{D}$ \\
\hline Vernonia sp1 & herb & - & - & $\mathrm{D} / \mathrm{S}$ \\
\hline Vernonia sp2 & herb & - & - & S \\
\hline Waltheria cf indica L. & herb & allochthonous & yes & $\mathrm{D}$ \\
\hline Xylopia aromatica (Lam.) Mart. & tree & autochthonous & no & $\mathrm{D}$ \\
\hline Zanthoxylum rhoifolium Lam. & tree & autochthonous & no & $\mathrm{D}$ \\
\hline Zornia curvata Mohlenbr. & herb & autochthonous & no & $\mathrm{S}$ \\
\hline
\end{tabular}

$\mathrm{D}=$ mounds; $\mathrm{S}=$ substrate rehabilitated with sewage sludge.

significant for CCA $(\mathrm{p}=0.001)$ and for axes 1 and 2 $(\mathrm{p}=0.001$ and 0.022 , respectively). The CCA ordination diagrams (Figure 4 ) and ANOSIM groups test $(\mathrm{p}=0.001)$ showed that the analyzed edaphic attributes were significantly different between the soil on mounds and the substrate rehabilitated with sewage sludge (Table 2). Likewise, the flora from these two biotopes was also significantly different. Procrustes test $(\mathrm{p}=0.001)$ showed high correlation between the edaphic variables and the floristic compositions in the two study biotopes $(\mathrm{r}=0.86)$.

The ordination diagram of species as a function of edaphic conditions (Figure 4) formed two distinct floristic groups: the first group associated with low edaphic fertility was composed of Acanthospermum australe, Aegiphila lhotzkiana, Annona tomentosa, Borreria latifolia, Byrsonima 
Table 2. Edaphic attributes of soil on mounds (D) and of rehabilitated substrate (S).

\begin{tabular}{cccccccccccc}
\hline Attribute & Sample & $\mathbf{O M}$ & $\mathbf{N}$ & $\mathbf{P}$ & $\mathbf{K}$ & $\mathbf{C a}$ & $\mathbf{M g}$ & $\mathbf{H}+\mathbf{A l}$ & $\mathbf{C E C}$ & $\mathbf{V} \%$ & $\mathbf{p H}$ \\
\multirow{2}{*}{ Mean } & $\mathrm{D}$ & $5.59 \mathrm{a}$ & $2.16 \mathrm{a}$ & $0.02 \mathrm{a}$ & $0.12 \mathrm{a}$ & $1.05 \mathrm{a}$ & $0.51 \mathrm{a}$ & $9.83 \mathrm{a}$ & $11.51 \mathrm{a}$ & $14.93 \mathrm{a}$ & $4.09 \mathrm{a}$ \\
& $\mathrm{S}$ & $7.94 \mathrm{~b}$ & $3.97 \mathrm{~b}$ & $0.91 \mathrm{~b}$ & $0.28 \mathrm{~b}$ & $4.44 \mathrm{~b}$ & $1.39 \mathrm{~b}$ & $9.02 \mathrm{a}$ & $15.75 \mathrm{~b}$ & $42.53 \mathrm{~b}$ & $4.85 \mathrm{~b}$ \\
\multirow{2}{*}{ Median } & $\mathrm{D}$ & $5.31 \mathrm{a}$ & $2.20 \mathrm{a}$ & $0.02 \mathrm{a}$ & $0.12 \mathrm{a}$ & $0.95 \mathrm{a}$ & $0.43 \mathrm{a}$ & $9.74 \mathrm{a}$ & $11.63 \mathrm{a}$ & $13.00 \mathrm{a}$ & $4.10 \mathrm{a}$ \\
& $\mathrm{S}$ & $8.25 \mathrm{~b}$ & $3.85 \mathrm{~b}$ & $0.88 \mathrm{~b}$ & $0.24 \mathrm{~b}$ & $4.30 \mathrm{~b}$ & $1.33 \mathrm{~b}$ & $9.44 \mathrm{a}$ & $15.98 \mathrm{~b}$ & $42.27 \mathrm{~b}$ & $4.80 \mathrm{~b}$ \\
\hline
\end{tabular}

$\mathrm{OM}=$ organic matter $\left(\right.$ dag. $\left.\mathrm{kg}^{-1}\right) ; \mathrm{N}=$ total nitrogen $\left(\mathrm{g} \cdot \mathrm{kg}^{-1}\right) ; \mathrm{P}=$ available phosphorus $\left(\mathrm{g} \cdot \mathrm{kg}^{-1}\right) ; \mathrm{K}=$ exchangeable potassium $\left(\mathrm{cmolc}^{\mathrm{kg}} \mathrm{kg}^{-1}\right) ;$ $\mathrm{Ca}=$ calcium $\left(\mathrm{cmolc} \cdot \mathrm{kg}^{-1}\right) ; \mathrm{Mg}=$ magnesium $\left(\mathrm{cmolc} \cdot \mathrm{Kg}^{-1}\right) ; \mathrm{H}^{+}+\mathrm{Al}^{3+}=$ potential acidity $\left(\mathrm{cmolc} . \mathrm{kg}^{-1}\right) ; \mathrm{CEC}=$ cation exchange capacity $\left(\mathrm{cmolc} . \mathrm{Kg}^{-1}\right) ; \mathrm{V} \%$ = base saturation (\%); and $\mathrm{pH}=$ active acidity; Means and medians for each attribute followed by the same letter do not statistically differ by Student's and Mood Median tests $(\mathrm{p}<0.05)$, respectively.

\section{Sampling units $\mathrm{x}$ edaphic attributes}

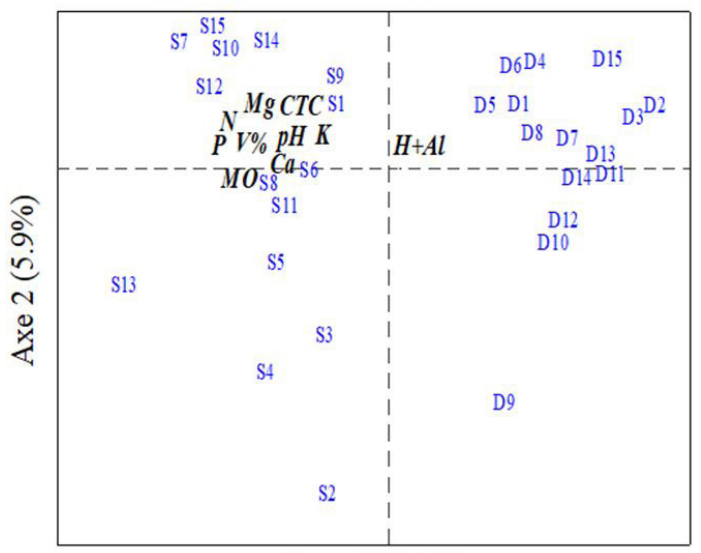

Axe $1(16.2 \%)$

\section{Plant species $x$ edaphic attributes}

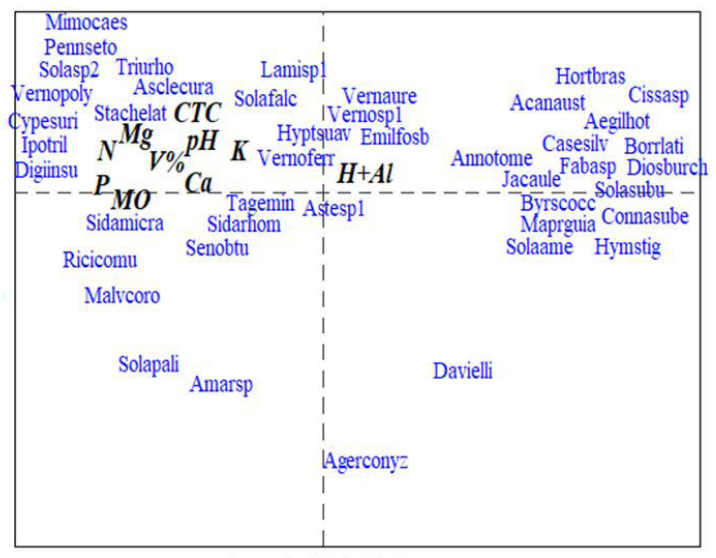

Axe $1(16.2 \%)$

Figure 4. Canonical Correspondence Analysis (CCA) ordination for distribution of sampling units (mounds = D1 to D15; and rehabilitated substrate $=$ S1 to S15) according to edaphic attributes (Table 2), and distribution of species (Table 1) influenced by edaphic attributes (Table 2). The first four letters of the generic and specific epithets abbreviated the scientific names of species.

coccolobifolia, Casearia Sylvestris, Connarus suberosus, Davilla elliptica, Diospyros burchellii, Hortia brasiliana, Hymenaea stigonocarpa, Jacaranda ulei, and Maprounea guianensis (Table 1). In this first group, $93 \%$ of species appeared exclusively on mounds and are autochthonous to Cerrado. The second group of plant species correlated with the fertility conditions present in the rehabilitated substrate (Table 2) and was composed of Asclepias curassavica, Cyperus surinamensis, Digitaria insularis, Ipomoea triloba, Malvastrum coromandelianum, Pennisetum setosum, Ricinus comunins, Senna obtusifolia, Sida rhombifolia, Sidastrum micranthum, Solanum falciforme, Solanum palinacanthum, Stachytarpheta elatior, Tagetes minuta, Triumfetta rhomboidea, Vernonanthura ferruginea, and Vernonia polyanthes. In this last group, 59\% of species are allochthonous and invasive of savannic formations of Cerrado.

\section{DISCUSSION}

The Cerrado biome has different expressions of vegetation climax such as grasslands, savannas, and forests (Eiten, 1972). These vegetation physiognomies grow under the same climate and are molded by particular soil conditions (Ratter et al., 2003; Moreno et al., 2008; Neri et al., 2012; Schaefer et al., 2015). Effective soil depth, course material along the soil profile, depth of the groundwater table, soil drainage degree, and soil fertility level define different Cerrado phytophysiognomies, vegetation expressions of the edaphic climax in the biome (Haridasan, 2008). 
In addition to these variations, floristic composition, phytosociology, and productivity can differ within the same physiognomy due to variations in soil fertility and physical characteristics (Haridasan, 2008). Despite the edaphic climax that rules the Cerrado flora, studies on the influence of edaphic conditions on plant colonization in mining sites are rather scarce (Starr et al., 2013).

Plant colonization starts with propagules entering a disturbed area, and these species must pass through abiotic filters prior to establishing an initial community in it (Hobbs \& Norton, 2004). The successful seedlings will be further submitted to biotic filters such as competition, facilitation, predation, and parasitism. In this sense, the intensity of each filter type will influence the level of environmental stress imposed on recovering communities during ecological succession (Hobbs \& Norton, 2004). Some studies suggest that edaphic limitations of exposed substrates and dominance of invasive grasses (Poaceae) are the major ecological filters restricting the establishment and growth of autochthonous species in areas degraded by mining activities (Goedert \& Corrêa, 2004; Martins et al., 2004; Halassy et al., 2016; Sollenberger et al., 2016).

In this study, portions of Cerrado vegetation remained on mounds and acted as sources of propagules within the mined landscape (Figure 2). Even though, only 17\% of the total sampled species (22 species) were common to the floristic communities on the mounds and on the rehabilitated substrate. Of these 22 species, 8 (44\%) were classified as autochthonous, and 10 (56\%) were classified as allochthonous and invasive of savanna formations of Cerrado (Table 1). In addition to the edaphic characteristics of each sampled biotope (Table 2), roots and underground stems that remain buried in substrates after mine exploitation (Corrêa et al., 1998) and low production and longevity of seeds from some Cerrado woody species (Salazar et al., 2012) may have influenced the low floristic similarity between the two plant communities within the same mined landscape. Long-term ecological studies indicate that the similarity between plant communities of a natural area of Cerrado and other area regenerated from deforestation is higher than the similarity between the same natural area and other area regenerated from mining activity (Corrêa \& Leite, 1998; Corrêa, 2009). Even in the absence of physical barriers, as it is the case of this study, species that inhabit closely neighboring locations can be allopatric (excluding) if soil conditions define different biotopes (Dajoz, 2005).

The number of plant species sampled on mounds (91) and on the rehabilitated substrate (62) (Table 1) was below the floristic richness found in savannic formations of Cerrado (Felfili et al., 2001; Munhoz \& Felfili, 2006). However, the number of woody species sampled in the mine rehabilitated with sewage sludge (Table 1) was within the range registered for mines abandoned to natural regeneration in the Brazilian Federal District (Corrêa et al., 2007). Allochthonous and invasive species of savanna and grassland formations of Cerrado were found both on the mounds under Cerrado vegetation cover and on the rehabilitated substrate (Table 1). Allochthonous species can become invasive and cause negative impacts to invaded environments (Sampaio \& Schmidt, 2013) due to their higher ability to compete and dominate plant communities relative to autochthonous species (Valéry et al. 2008).

Sewage sludge applied to the mined surface at $130 \mathrm{Mg} \mathrm{ha}^{-1}$ increased substrate fertility to levels far above those measured in the soil under the natural vegetation cover (Table 2) and in Cerrado soils under agricultural production (Correia et al., 2004). The rehabilitated substrate was dominated by grass species (Poaceae) and, even in areas under savanna vegetation cover, additions of phosphorus and nitrogen have favored the dominance of invasive grasses to the detriment of autochthonous species (Bustamante et al., 2012; Lannes et al., 2015). Studies on plant nutrition have shown that the majority of autochthonous species of Cerrado are resistant or tolerant to the dystrophy condition of Cerrado soils (Haridasan, 2008), and that high levels of soil fertility favor the establishment of allochthonous and invasive plant species in detriment of autochthonous ones (Holmes, 2001; Foster et al., 2009; Daws et al., 2013; Nussbaumer et al., 2016). Colonization and dominance of invasive species seem to be a common side effect in exploited mines where substrate fertility has increased above dystrophic levels (Silva et al., 2013).

\section{CONCLUSIONS}

The incorporation of sewage sludge into the mining substrate created an edaphic environment chemically distinct from the original soil of the study area. A plant 
community primarily composed of allochthonous and invasive species spontaneously recruited on such fertile environment in detriment to the plant species present in the remaining portions of Cerrado within the mined landscape. The edaphic environment built with sewage sludge acted as a filter in assembling a distinct plant community compared to the native Cerrado vegetation.

\section{SUBMISSION STATUS}

Received: 13 oct., 2017

Accepted: 12 mar., 2018

\section{CORRESPONDENCE TO}

\section{Alexander Balduíno}

Universidade de Brasília - UnB, SQN

106, Bloco C, ap. 605, Bairro Asa Norte,

CEP 70742-030, Brasília, DF, Brasil

e-mail: ibama.alexander@gmail.com

\section{REFERENCES}

Andrés F, Walter I, Tenorio JL. Revegetation of abandoned agricultural land amended with biosolids. The Science of the Total Environment 2007; 378(1-2): 81-83. http://dx.doi. org/10.1016/j.scitotenv.2007.01.017. PMid:17306339.

Borges TA, Silva CB, Balduíno APC, Soares JA, Pereira CEB. Uso de biossólido na recuperação de área degradada no Distrito Federal. Revista AIDIS de Ingeniería y Ciencias Ambientales [online] 2009 [cited 2017 Apr 6]. 2(1): 66-75. Available from: http://www.revistas.unam.mx/index.php/ aidis/article/view/13106/0

Bustamante MMC, Brito DQ, Kozovits AR, Luedemann G, Mello TRB, Pinto AS et al. Effects of nutrient additions on plant biomass and diversity of the herbaceous-subshrub layer of a Brazilian savanna (Cerrado). Plant Ecology 2012; 213(5): 795-808. http://dx.doi.org/10.1007/s11258012-0042-4.

Cleland EE, Larios L, Suding KN. Strengthening invasion filters to reassemble native plant communities: soil resources and phenological overlap. Restoration Ecology 2013; 21(3): 390-398. http://dx.doi.org/10.1111/j.1526100X.2012.00896.x.

Companhia de Planejamento do Distrito Federal CODEPLAN. Geo Serviço [online]. 2017 [cited 2017 Apr 6]. Available from: http://www.codeplan.df.gov.br/ component/content/article/331-geo-servico/306-geoservico.html
Corrêa RS, Balduíno APC, Teza CTV, Baptista GMM, Silva DJ. Recuperação da cobertura vegetal e da atividade fotossintética em jazidas revegetadas no Distrito Federal. Revista Brasileira de Ciências Ambientais 2017; 46(46): 75-87. http://dx.doi.org/10.5327/Z2176-947820170208.

Corrêa RS, Bento MAB. Qualidade do substrato minerado de uma área de empréstimo revegetada no Distrito Federal. Revista Brasileira de Ciência do Solo 2010; 34(4): 1435-1444. http://dx.doi.org/10.1590/S0100-06832010000400039.

Corrêa RS, Bias ES, Baptista GMM. Áreas degradadas pela mineração no Distrito Federal. In: Corrêa RS, Mello Baptista GMM, editores. Mineração e áreas degradadas no Cerrado. Brasília: Universa; 2004.

Corrêa RS, Leite LL, Bastos EK. A dinâmica da degradação e da regeneração. In: Corrêa RS, Baptista GMM, editores. Ecologia e recuperação de áreas degradadas no Cerrado. Brasília: Paralelo 15; 1998.

Corrêa RS, Leite LL. Desmatamento e mineração em unidades de conservação. In: Corrêa RS, Baptista GMM, editores. Ecologia e recuperação de áreas degradadas no Cerrado. Brasília: Paralelo 15; 1998.

Corrêa RS, Melo B Fo, Baptista GMM. Avaliação fitossociológica da sucessão autogênica em áreas mineradas no Distrito Federal. Cerne [online]. 2007 [cited $2017 \mathrm{Apr}$ 6]. 13(4): 406-415. Available from: http://www.redalyc. org /html/744/74413409/

Corrêa RS. Recuperação de áreas degradadas pela mineração no Cerrado. 2. ed. Brasília: Universa; 2009.

Correia JR, Reatto A, Spera ST. Solos e suas relações com o uso e manejo. In: Souza DMG, Lobato E, editores. Cerrado: correção do solo e adubação. 2. ed. Brasília: Embrapa Informação Tecnológica; 2004.

Dajoz R. Ecologia geral. Porto Alegre: Artmed; 2005.

Daws MI, Standish RJ, Koch JM, Morald TK. Nitrogen and phosphorus fertilizer regime affect jarrah forest restoration after bauxite mining in Western Australia. Applied Vegetation Science 2013; 16(4): 610-618. http:// dx.doi.org/10.1111/avsc.12046.

De Maria IC, Kocssi MA, Dechen SCF. Agregação do solo em área que recebeu biossólido. Bragantia 2007; 66(2): 291298. http://dx.doi.org/10.1590/S0006-87052007000200013.

Domene X, Mattana S, Ramírez W, Colón J, Jiménez P, Balanyà $T$ et al. Bioassays prove the suitability of mining debris mixed with sewage sludge for land reclamation purposes. Journal of Soils and Sediments 2010; 10(1): 30-44. http://dx.doi.org/10.1007/s11368-009-0073-1.

Eiten G. The Cerrado vegetation of Brazil. Botanical Review 1972; 38(2): 201-341. http://dx.doi.org/10.1007/ BF02859158.

Embrapa Brasileira de Pesquisa Agropecuária - EMBRAPA. Manual de métodos de análise de solos. 2. ed. Rio de Janeiro: Embrapa Informação Tecnológica; 1997. 
Embrapa Brasileira de Pesquisa Agropecuária - EMBRAPA. Sistema Brasileiro de Classificação de Solos. 3. ed. Brasília: Embrapa Informação Tecnológica; 2013.

Felfili JM, Sevilha AC, Silva MC Jr. Comparação entre as unidades fisiográficas Chapada Pratinha, Veadeiros e Espigão Mestre do São Francisco. In: Felfili JM, Silva MC Jr, editores. Biogeografia do bioma Cerrado: estudo fitofisionômico da Chapada do Espigão Mestre do São Francisco. Brasíla: Universidade de Brasília; 2001.

Foster BL, Kindscher K, Houseman GR, Murphy CA. Effects of hay management and native species sowing on grassland community structure, biomass, and restoration. Ecological Applications 2009; 19(7): 1884-1896. http:// dx.doi.org/10.1890/08-0849.1. PMid:19831077.

Funk JL, Cleland EE, Suding KN, Zavaleta ES. Restoration through reassembly plant traits and invasion resistance. Trends in Ecology \& Evolution 2008; 23(12): 695-703. http:// dx.doi.org/10.1016/j.tree.2008.07.013. PMid:18951652.

Gardner WC, Broersma K, Naeth A, Chanasyk D, Jobson AL. Influence of biosolids and fertilizer amendments on physical, chemical and microbiological properties of copper mine tailings. Canadian Journal of Soil Science 2010; 90(4): 571-583. http://dx.doi.org/10.4141/cjss09067

Gauch HC. Multivariate analysis in community ecology. Cambridge: Editora Cambridge University; 1982. http:// dx.doi.org/10.1017/CBO9780511623332.

Goedert WJ, Corrêa RS. Usos, degradação e qualidade do solo. In: Corrêa RS, Baptista GMM, organizadores. Mineração e áreas degradadas no Cerrado. Brasília: Universa; 2004.

Halassy M, Singh AN, Szabo R, Szili-Kovacs T, Szitar K, Torok K. The application of a filter-based assembly model to develop best practices for Pannonian sand grassland restoration. Journal of Applied Ecology 2016; 53(3): 765773. http://dx.doi.org/10.1111/1365-2664.12618.

Haridasan M. Nutritional adaptations of native plants of the cerrado biome in acid soils. Brazilian Journal of Plant Physiology 2008; 20(3): 183-195. http://dx.doi.org/10.1590/ S1677-04202008000300003.

Hobbs RJ, Norton DA. Ecological filters, thresholds, and gradients in resistance to ecosystem reassembly. In: Temperton VM, Hobbs RJ, Nuttle T, Halle S, editors. Assembly rules and restoration ecology: bridging the gap between theory and practice. Washington: Island Press; 2004.

Holmes PM. Shrubland restauration following woody alien invasion and mining: Effects of topsoil depth seed source, and fertilizer addition. Restoration Ecology 2001; 9(1): 71-84. http://dx.doi.org/10.1046/j.1526-100x.2001.009001071.x.

Hulvey KB, Aigner PA. Using filter-based community assembly models to improve restoration outcomes. Journal of Applied Ecology 2014; 51(4): 997-1005. http://dx.doi. org/10.1111/1365-2664.12275.
Jordán MM, García-Sánchez E, Almendro-Gandel MB, Pardo F, Vicente AB, Sanfeliu T et al. Technosols designed for rehabilitation of mining activities using mine spoils and biosolids. Ion mobility and correlations using percolation columns. Catena 2017; 148: 74-80. http:// dx.doi.org/10.1016/j.catena.2016.02.027.

Lannes LS, Bustamante MMC, Edwards PJ, Venterink HO. Native and alien herbaceous plants in Brazilian Cerrado are (co-) limited by different nutrients. Plant and Soil 2015; 400(1-2): 231-243. http://dx.doi.org/10.1007/ s11104-015-2725-9.

Lorenzi H. Plantas daninhas do Brasil: terrestres, aquáticas, parasitas e tóxicas. 4. ed. São Paulo: Instituto Pantarum; 2008.

Martins CR, Leite LL, Haridasan M. Capim-gordura (Melinis minutiflora P. Beauv.), uma gramínea exótica que compromete a recuperação de áreas degradadas em unidades de conservação. Revista Árvore 2004; [cited 2017 Apr 6]; 28(5): 739-747. Available from: https://www. researchgate.net/publication/ 262432754

Mendonça RC, Felfili JM, Walter BMT, Silva MC Jr, Rezende AV, Filgueiras TS et al. Flora vascular do bioma Cerrado: Checklist com 12.356 espécies. In: Sano SM, Almeida SP, Ribeiro JF, editores. Cerrado: ecologia e flora. Brasília: Embrapa Informação Tecnológica; 2008. 2 vol.

Moreno MIC, Schiavini I, Haridasan M. Fatores edáficos influenciando na estrutura de fitofisionomias do Cerrado. Caminhos de Geografia [online]. 2008 [cited 2017 Apr 6]; 9(25): 173-194. Available from: http://www.ig.ufu .br/ revista/caminhos.html

Munhoz CBR, Felfili JM. Fitossociologia do estrato herbáceo-subarbustivo de uma área de campo sujo no Distrito Federal, Brasil. Acta Botanica Brasílica 2006; 20(3): 671-685. http://dx.doi.org/10.1590/S010233062006000300017 .

Neri AV, Schaefer CER, Silva AF, Souza AL, FerreiraJúnior WG, Meira-Neto JAA. The influence of soils on the floristic composition and community structure of an area of brazilian Cerrado vegetation. Edinburgh Journal of Botany 2012; 69(01): 1-27. http://dx.doi.org/10.1017/ S0960428611000382.

Nussbaumer YV, Cole MA, Offler CE, Patrick JW. Identifying and ameliorating nutrient limitations to reconstructing a forest ecosystem on mined land. Restoration Ecology 2016; 24(2): 202-211. http://dx.doi.org/10.1111/rec.12294.

Oster M, Ask K, Cousins SAO, Eriksson O. Dispersal and establishment limitation reduces the potencial for successful restoration of semi-natural grassland communities on former arable fields. Journal of Applied Ecology 2009; 46: 1266-1274.

R Core Team. R: a language and environment for statistical computing [online]. Vienna: R Foundation for Statistical Computing; 2016 [cited 2017 Apr 6]. Available from: https://www.R-project.org/ 
Ratter JA, Bridgewater S, Ribeiro JF. Analysis of the floristic composition of the Brazilian Cerrado vegetation III: comparasion of the woody vegetation of 376 areas. Edinburgh Journal of Botany 2003; 60(1): 57-109. http:// dx.doi.org/10.1017/S0960428603000064.

Salazar A, Goldstein G, Franco AC, Miralles-Wilhelm F. Seed limitation of woody plants in Neotropical savannas. Plant Ecology 2012; 213(2): 273-287. http://dx.doi. org/10.1007/s11258-011-9973-4.

Sampaio AB, Schmidt IB. Espécies exóticas invasoras em unidades de conservação federais do Brasil. Biodiversidade Brasileira [online]. 2013 [cited 2017 Apr 6]; 3(2): 32-49. Available from: http://www.icmbio.gov.br/revistaeletro nica/index.php/BioBR/article/view/351/362

Schaefer CEGR, Nunes JA, Neri AV, Mendonça AF, FerreiraJúnior WG, Arruda DM et al. Relações solo-vegetação em formações brasileiras: metodologia e estudos de caso. In: Eisenlohr PV, Felfili JM, Melo MMRF, Andrade LA, Meira-Neto JAA, editores. Fitossociologia no Brasil: métodos e estudos de casos. Viçosa: Ed. UFV; 2015. 2 vol.

Species Link. Sistema distribuído de informação que integra dados primários de coleções científicas [online]. 2017 [cited 2017 Apr 6]. Available from: http://splink.cria.org.br/

Silva LCR, Corrêa RS, Doane TA, Pereira EIP, Horwath WR. Unprecedented carbon accumulation in mined soils: the synergistic effect of resource input and plant species invasion. Ecological Applications 2013; 23(6): 1345-1356. http://dx.doi.org/10.1890/12-1957.1. PMid:24147407.
Sollenberger D, Kadlec C, O'Shaughnessy J, EgertonWarburton L. Environmental filtering mediates grassland community assembly following restoration with soil carbon additions. Restoration Ecology 2016; 24(5): 626636. http://dx.doi.org/10.1111/rec.12362.

Starr CR, Corrêa RS, Filgueiras TS, Hay JDV, Santos PF. Plant colonization in a gravel mine revegetated with Stylosanthes spp. in a neotropical savanna. Landscape and Ecological Engineering 2013; 9(1): 189-201. http:// dx.doi.org/10.1007/s11355-012-0196-1.

Ter Braak CJF. The analysis of vegetation-environment relationships by canonical correspondence analysis. Vegetatio 1987; 69(1-3): 69-77. http://dx.doi.org/10.1007/ BF00038688

Ter Braak CJF, Prentice IC. A theory of gradient analysis. Advances in Ecological Research 1988; 18: 271-317. http:// dx.doi.org/10.1016/S0065-2504(08)60183-X.

Torri SI, Corrêa RS, Renella G. Soil carbon sequestration resulting from biosolids application. Applied and Environmental Soil Science 2014; 2014: 1-9. http://dx.doi. org/10.1155/2014/821768.

Valéry L, Fritz H, Lefeuvre JC, Simberloff D. In search of a real definition of the biological invasion phenomenon itself. Biological Invasions 2008; 10(8): 1345-1351. http:// dx.doi.org/10.1007/s10530-007-9209-7.

Wijesekara H, Bolan NS, Vithanage M, Xu Y, Mandal S, Brown SL et al. Utilization of biowaste for mine spoil rehabilitation. Advances in Agronomy 2016; 138: 97-173. http://dx.doi.org/10.1016/bs.agron.2016.03.001. 